\title{
Investigation of anti-cancer and migrastatic properties of novel curcumin derivatives on breast and ovarian cancer cell lines
}

\author{
Jinsha Koroth ${ }^{1,2}$, Snehal Nirgude ${ }^{1,2}$, Shweta Tiwari ${ }^{4}$, Vidya Gopalakrishnan ${ }^{1,2,3}$, Raghunandan Mahadeva ${ }^{1}$,
} Sujeet Kumar ${ }^{4}$, Subhas S. Karki ${ }^{4}$ and Bibha Choudhary ${ }^{1 *}$ (D)

\begin{abstract}
Background: Curcumin is known for its multitude of medicinal properties, including anti-cancer and migrastatic activity. Efforts to overcome poor bioavailability, stability, and side effects associated with the higher dose of curcumin has led to the development of newer derivatives of curcumin. Thus, the focus of this study is to screen novel curcumin derivatives, namely ST03 and ST08, which have not been reported before, for their cytotoxicity and migrastatic property on cancer cells.

Methods: Anti-cancer activity of ST03 and ST08 was carried out using standard cytotoxicity assays viz., LDH, MTT, and Trypan blue on both solid and liquid cancer types. Flow cytometric assays and western blotting was used to investigate the cell death mechanisms. Transwell migration assay was carried out to check for migrastatic properties of the compounds.

Results: Both the compounds, ST03 and ST08, showed 100 fold higher potency on liquid and solid tumour cell lines compared to its parent compound curcumin. They induced cytotoxicity by activating the intrinsic pathway of apoptosis in the breast (MDA-MB-231) and ovarian cancer cell lines (PA-1) bearing metastatic and stem cell properties, respectively. Moreover, ST08 also showed inhibition on breast cancer cell migration by inhibiting MMP1 (matrix metalloproteinase 1).

Conclusion: Both ST03 and ST08 exhibit anti-cancer activity at nanomolar concentration. They induce cell death by activating the intrinsic pathway of apoptosis. Also, they inhibit migration of the cancer cells by inhibiting MMP1 in breast cancer cells.
\end{abstract}

Keywords: Cancer therapy, Curcumin derivatives, PA1, MDA-MB-231, Anti-cancer, Migrastatic

\section{Background}

Cancer is a disease characterized by abnormal proliferation of cells, which can evade anti-growth signals and invade other parts of the body [1]. Cancer cells thus affect the normal functioning of the organ, impairing the homeostasis of the body [2]. Various therapeutic strategies such as chemotherapy, hormone therapy, immunotherapy, radiation therapy, targeted therapy, gene therapy, have been utilized for the effective management of the disease [3, 4]. Despite having very advanced

\footnotetext{
* Correspondence: vibhachou@gmail.com

${ }^{1}$ Institute of Bioinformatics and Applied Biotechnology, Electronic City Phase

1, Bangalore, Karnataka 560100, India

Full list of author information is available at the end of the article
}

treatment, metastasis, and cancer relapse with resistance remain a significant challenge in cancer treatment. The resistance to treatment is due to a subpopulation of cells, called cancer stem cells [5, 6]. Recent evidence has shown that cancer stem cells undergo continuous mutations and are responsible for drug resistance and relapse. Targeting cancer stem cells is challenging, but identifying drugs which can work on stem cells can solve the relapse and resistance seen in most of the high-grade tumors [7].

Currently, cancer reports show that around 8.2 million people around the globe are suffering from the irreversible metastatic condition of malignant tumors with drug resistance [8]. Malignant tumors, characterized by its 
invasive and metastatic nature, increases the morbidity and mortality rates seen in cancer patients [9]. Cancer cell produces extracellular matrix-degrading enzymes (MMPs), which help metastasize [10]. Relocalization of malignant cells to distant organs leads to secondary tumor growth even after the complete removal of the tumor from the primary site. Available chemo-therapeutic drugs do not efficiently work on metastasized cancer cells [10]. Therefore, given the above facts, the challenge is to eliminate cancerpromoting cells (cancer stem cells) selectively.

Several natural compounds have shown to have anticancer activity. Among them Curcumin (Fig. 1) (1,7-bis (4-hydroxy 3-methoxyphenyl)-1,6-heptadione-3,5-dione or diferuloylmethane), has been shown to have anticancer on an array of cancer cells regardless of their origin [11-13]. Curcumin is derived from turmeric, and is known for it's anti-inflammatory, anti-oxidant, antibacterial and anti-malarial properties [14, 15]. Studies have shown that curcumin can target cancer stem cells $[16,17]$ as well as inhibit cancer cell migration [8]. Curcumin has been shown to act on cancer stem cells of colorectal cancer, pancreatic cancer, breast cancer, brain cancer, and head and neck cancer [17]. Curcumin exhibits its anti-metastatic property by altering several signaling mechanisms, including inhibition of transcription factors, proteases, protein kinases, inflammatory cytokines, and their signaling pathways [10].

Although curcumin is known for its multitude of activities, it lacks stability and is not bioavailable in the in vivo system [18]. So to enhance the metabolic stability, various modifications were made onto the curcumin structures. DAPs (diarylidenyl-piperidone) is one of the well-studied groups of curcumin derivatives, which exhibited proliferation inhibition on multiple cancer cell lines such as colon, breast, ovarian epithelial cancer, etc. and multidrug resistance reverting property as well [19-23]. The multi-targeted effect of these compounds is documented to have more advantages than the single targeted ligands, as it can interfere with multiple signaling pathways and can have a pleiotropic effect [24-27]. S. Das et al, have synthesized and demonstrated anti-cancer property of molecular dimers. They have conjugated two moieties of (3E, 5E)-3,5-dibenzylidenepiperidin-4-one pharmacophores via oxamide/propane diamide linkage. Their group has shown the anti-leukemic and anti-lymphoma activity of few 1,2-bis[(3E,5E)-3,5-dibenzylidene-4-oxo-1piperidyl]ethane-1,2-dione derivatives [28-31]. The dimers of DAPs or 1,2-bis[(3E,5E)-3,5-dibenzylidene-4-oxo-1piperidyl]ethane-1,2-dione attracted scientific attention to use as backbone structure due to its anti-cancer effect on various cancer types by activating the apoptotic pathway [29]. 1,2-bis[(3E,5E)-3,5-dibenzylidene-4-oxo1-piperidyl] ethane-1,2-diones are thus considered as an excellent drug prototype for the development of novel compounds.

The dimers are relatively more stable than curcumin and also known to enhance the anticancer properties. Keeping the backbone of dimer constant, we synthesized two novel compounds, (ST03 (1,2-bis[(3E,5E)-3,5-bis[(2 -chlorophenyl)methylene]-4-oxo-1-piperidyl] ethane-1,2-dione) and ST08 ([4-[(E)-[(5E)-1-[2-[(3E,5E)-3,5-bis[(4-hydro xyazonylphenyl)methylene]-4-oxo-1-piperidyl]-2-oxoacetyl]-5-[(4-hydroxyazonylphenyl)methylene]-4-oxo3-piperidylidene]methyl]phenyl] azinic acid)). We have checked anti-cancer activities of both the compounds on solid and liquid cancer cells. We have also investigated ST03 and ST08 induced cell death mechanism as well as their migrastatic property. We have carried out these studies on two major gynecological cancer types, breast, and ovarian cancer [32] using breast and ovarian cancer cell lines, respectively.

\section{Methods}

\section{Chemistry}

Silica gel plates were used for Thin Layer Chromatography by using toluene and ethyl acetate in 1:1 proportion. The IR spectra were recorded in $\mathrm{KBr}$ on a Jasco 430+ (Jasco, Japan); the ${ }^{1} \mathrm{H}$ NMR spectra were recorded in $\mathrm{CDCl}_{3} / \mathrm{DMSO}$ on a Bruker $(400 \mathrm{MHz})$, and $\mathrm{J}$ values were reported in Hertz $(\mathrm{Hz})$. Mass spectra were

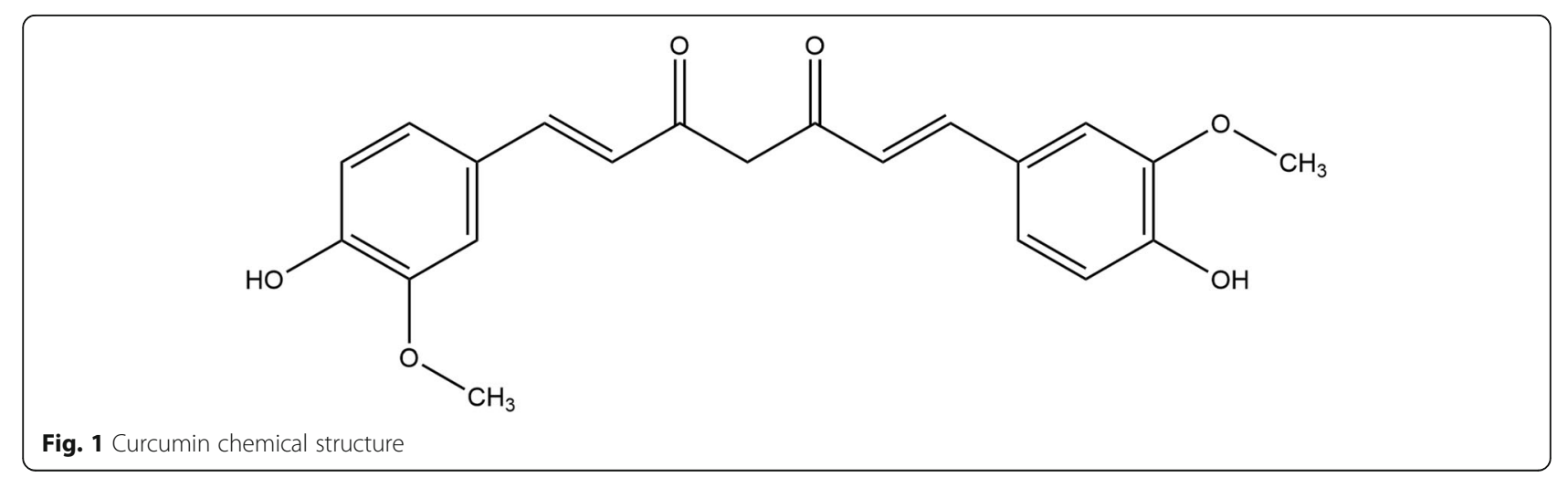


recorded in triple quadrupole LCMS-6410 from Agilent technologies.

\section{Procedure for synthesis of ST03 and ST08}

\section{ST03 Step 1.}

Oxaloyl chloride $(0.003 \mathrm{~mol}, 0.39 \mathrm{~g})$ in DCE $(5 \mathrm{~mL})$ was added dropwise to a stirred suspension of a 3,5-bis (2-chlorobenzylidene)piperidin-4-one $(0.006 \mathrm{~mol}) \quad$ in DCE $(20 \mathrm{~mL})$ containing triethylamine $(0.006 \mathrm{~mol}, 0.61$ g) at $20{ }^{\circ} \mathrm{C}$ for a period of $30 \mathrm{~min}$. The reaction was stirred at room temperature for $12 \mathrm{~h}$. The solvent was removed under reduced pressure at $45{ }^{\circ} \mathrm{C}$. An aqueous solution of potassium carbonate $(25 \mathrm{~mL}, 5 \% \mathrm{w} / \mathrm{v})$ was added to the crude mass and stirred for $2 \mathrm{~h}$. The solid obtained was fifiltered, dried, and crystallized from 95\% ethanol to yield the pure product.

Step 2:

The 2-chlorobenzaldehyde $(26.71 \mathrm{mmol})$ was added dropwise to a suspension of 4-piperidone hydrochloride monohydrate $(13.03 \mathrm{mmol})$ in acetic acid $(35 \mathrm{~mL})$. Dry hydrogen chloride gas was passed through this mixture until a clear solution was obtained. After stirring the reaction mixture at room temperature for $24 \mathrm{~h}$, the precipitate was separated through filtration and added to a mixture of a saturated aqueous potassium carbonate solution $(25 \% \mathrm{w} / \mathrm{v}, 25 \mathrm{~mL})$ and acetone $(25 \mathrm{~mL})$; the resultant mixture was stirred for $0.5 \mathrm{~h}$. The free base was collected, washed with water $(50 \mathrm{~mL})$, and dried. The compound was recrystallized from 95\% ethanol to get the pure compound.

\section{ST08 Step 1:}

The 4-nitrobenzaldehyde $(26.71 \mathrm{mmol}) \quad$ was added dropwise to a suspension of 4-piperidone hydrochloride monohydrate $(13.03 \mathrm{mmol})$ in acetic acid $(35 \mathrm{~mL})$. Dry hydrogen chloride gas was passed through this mixture until a clear solution was obtained. After stirring the reaction mixture at room temperature for $24 \mathrm{~h}$, the precipitate was separated through filtration and added to a mixture of a saturated aqueous potassium carbonate solution $(25 \% \mathrm{w} / \mathrm{v}, 25 \mathrm{~mL})$ and acetone $(25 \mathrm{~mL})$; the resultant mixture was stirred for $0.5 \mathrm{~h}$. The free base was collected, washed with water $(50 \mathrm{~mL})$, and dried. The compound was recrystallized from $95 \%$ ethanol to get the pure compound.

Step 2:

Oxaloyl chloride $(0.003 \mathrm{~mol}, 0.39 \mathrm{~g})$ in DCE $(1,2$ Dichloroethane) $(5 \mathrm{~mL})$ was added dropwise to a stirred suspension of a 3,5-bis (4-nitrobenzylidene)piperidin-4one $(0.006 \mathrm{~mol})$ in DCE $(20 \mathrm{~mL})$ containing triethylamine $(0.006 \mathrm{~mol}, 0.61 \mathrm{~g})$ at $20^{\circ} \mathrm{C}$ for a period of $30 \mathrm{~min}$. The reaction was stirred at room temperature for $12 \mathrm{~h}$. The solvent was removed under reduced pressure at $45^{\circ} \mathrm{C}$. An aqueous solution of potassium carbonate $(25$ $\mathrm{mL}, 5 \% \mathrm{w} / \mathrm{v})$ was added to the crude mass and stirred for $2 \mathrm{~h}$. The solid obtained was filtered, dried, and crystallized from $95 \%$ ethanol to yield the pure product.

ST-03: Yield $45 \%$, Rf 0.63 , MP. $140-145^{\circ} \mathrm{C}$, IR $(\lambda \mathrm{cm}$ $\left.{ }^{-1}\right)$ 3061, 2975, 1642, 1440, 1260, 1044, 990. ${ }^{1} \mathrm{H}$ NMR

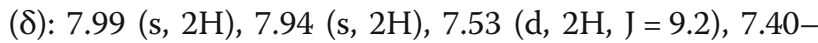
$7.31(\mathrm{~m}, 6 \mathrm{H}), 7.23(\mathrm{~d}, 4 \mathrm{H}, \mathrm{J} 8.8), 7.18-7.14(\mathrm{~m}, 2 \mathrm{H}), 7.05$ $(\mathrm{d}, 2 \mathrm{H}, \mathrm{J}=9.2), 4.38(\mathrm{~s}, 4 \mathrm{H}), 4.34(\mathrm{~s}, 4 \mathrm{H}) . \mathrm{MS}(\mathrm{ESI}) \mathrm{m} / \mathrm{z}$ : 742.53 (742.47).

ST-08: Yield $40 \%$, Rf 0.55 , MP. $180-182^{\circ} \mathrm{C}$, Nitro derivative $\operatorname{IR}\left(\lambda \mathrm{cm}^{-1}\right) 3075,2932,2851,1666,1599,1520$,

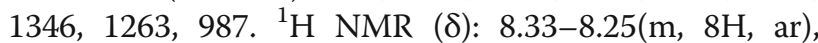
7.77(s, 2H), $7.70(\mathrm{~d}, 4 \mathrm{H}, \mathrm{J}=8.8 \mathrm{~Hz}), 7.63(\mathrm{~d}, 4 \mathrm{H}, \mathrm{J}=8.8$ $\mathrm{Hz}), 7.50$ (s, 2H), 4.54 (s, $4 \mathrm{HO}, 4.48$ (s, 4H)). MS (ESI) $\mathrm{m} / \mathrm{z}: 781.58$ (784.68).

\section{Cell lines and culture}

In order to investigate the anti-cancer activity of ST03 and ST08 on solid and liquid type of cancers, they were tested on multiple human cancer cell lines. Human cancer cell lines such as PA1 (ovarian teratocarcinoma cell line), MCF7 (breast adenocarcinoma cell line), MDAMB-231(breast adenocarcinoma cell line), CEM ( $\mathrm{T}$ acute lymphoblastic leukemia cell line), K562 (B chronic myelogenous leukemia cell line), A431 (epidermoid carcinoma cell line), HeLa (cervical adenocarcinoma cell line) and $293 \mathrm{~T}$ (embryonic kidney cell line) cells were purchased from NCCS, Pune, India. A2780 (ovarian endometrioid adenocarcinoma) was purchased from ATCC and Nalm6 (B cell precursor leukaemia cell line) was a kind gift from SCR lab, IISc, Bangalore, India). CEM, K562, Nalm6 cell lines were grown in RPMI-1640 (Lonza). PA1, MCF7, HeLa, A431 were grown in MEM and MDA-MB-231, $293 \mathrm{~T}$ cell lines were grown in DMEM media (Lonza). All cell lines were supplemented with 10\% Fetal bovine serum and 1X antibioticantimycotic (GIBCO, Thermo Fisher Scientific, US) and maintained at $37 \mathrm{C}$ in a humidified incubator with 5\% $\mathrm{CO}_{2}$ supply. Cytotoxicity of these compounds on normal cells was examined using peripheral blood mononuclear cells (a kind gift from SCR lab, IISc, Bangalore, India) and $293 \mathrm{~T}$ cells.

\section{MTT assay}

Cytotoxicity exerted by ST compounds on cell lines were assessed by doing 3-(4,5-dimethylthiazol-2-yl)-2,5-diphenyltetrazolium bromide assay (MTT assay) [33]. Cells were seeded (5000 cells/well) in 96-well plate in triplicates, incubated for $24 \mathrm{~h}$, and treated with respective ST compounds from $1 \mathrm{nM}$ to $1000 \mathrm{nM}$. Curcumin was used for comparing the potency with its derivatives. Curcumin was added in the range of $1 \mathrm{uM}$ to $100 \mathrm{uM}$ concentrations to compare the cytotoxicity with its derivatives. 
After 48 and $72 \mathrm{~h}$ incubation, $10 \mu \mathrm{l}$ of MTT $(5 \mathrm{mg} /$ $\mathrm{mL}$ ) reagent was added to each well to a final concentration of $0.25 \mathrm{mg} / \mathrm{mL}$ and incubated till the colour developed. Following colour development, the reaction was stopped by adding stopping solution (50\% N, N-Dimethylformamide) (Sigma-Aldrich, USA), 10\% Sodium dodecyl sulfate, (MP Biomedicals, USA) and kept for $2 \mathrm{~h}$ incubation at $37 \mathrm{C}$ for complete solubilization of formazan crystal. Absorbance was measured at $570 \mathrm{~nm}$ on a 96 well plate reader (Tecan infinite 200 ELISA plate reader, Tecan Trading AG, Switzerland). Absorbance from culture medium without cells was considered as blank and was subtracted. Cells treated with an appropriate concentration of DMSO was used as vehicle control as the compounds were dissolved in DMSO. The 50\% inhibition concentration of the drugs ( $\mathrm{IC}_{50}$ values) were calculated from the $48 \mathrm{~h}$ treatment readings using GraphPad Prism 7 software. Percentage of viable cells in each treatment concentrations were calculated as a ratio of sample OD to the control OD.

\section{LDH assay}

Lactate dehydrogenase (LDH) release is an indication of cell injury. This assay quantitatively measures the stable LDH in the cytosol. To perform this assay, 5000 cells/ well were seeded in 96-well plate in triplicates and were treated with ST compounds ( $1 \mathrm{nM}$ to $1000 \mathrm{nM})$. After 48 and $72 \mathrm{~h}$ of treatment, each well of 96-well plate was washed to remove FBS content and the cells were lysed using $0.5 \%$ Triton-X-100 prepared in $1 \mathrm{X}$ Phosphate buffer saline. This lysate was mixed with LDH assay reagents, described by OPS Diagnostics LLC, P.O. Box 348, Lebanon, NJ 08833 USA. The absorbance of the orange-red colored formazan product was measured at $490 \mathrm{~nm}$ using Tecan infinite 200 ELISA plate reader (Tecan Trading AG, Switzerland).

\section{Trypan blue exclusion assay}

The cytotoxic effect of ST compounds on the viability of cancer cell lines was determined by Trypan blue exclusion assay [33]. The cells were seeded in 6 well culture plate at a density of 75,000 cells $/ \mathrm{mL}$ and incubated for $24 \mathrm{~h}$ and treated with different concentrations of ST compounds ( $1 \mathrm{nM}$ to $1000 \mathrm{nM})$. Cells were collected at $48 \mathrm{~h}$ and $72 \mathrm{~h}$ time points and resuspended in $0.4 \%$ of trypan blue (Sigma-Aldrich, USA). The number of viable cells was counted using hemocytometer. Percentage of viable cells in each treatment concentrations were calculated as a ratio of sample cell count to the control cell count. The $\mathrm{IC}_{50}$ values $(50 \%$ inhibition concentration of the drugs) were calculated from the $48 \mathrm{~h}$ data.

\section{Phosphatidylserine externalization assay using AnnexinV-} FITC/PI

In order to understand the mode of cell death (apoptosis/necrosis) induced by ST compounds in ovarian and breast cancer cells, annexin V-FITC/PI staining was carried out. Cells grown in 6-well plate with a cell density of 75,000 cells $/ \mathrm{mL}$ were treated with ST compounds for $48 \mathrm{~h}$. Cells were trypsinized, washed with ice-cold $1 \mathrm{X}$ Phosphate buffer saline and resuspended in $1 \mathrm{X}$ annexin binding buffer containing annexin V-FITC antibody (Biolegend, San Diego, CA) for 15 min in the dark on ice. PI (propidium iodide) was added $(3.3 \mu \mathrm{g} / \mathrm{mL})$ just before acquiring the samples. Cells incubated in $3 \%$ paraformaldehyde was used as a positive control. A total of 10,000 events were acquired for each sample using Beckman coulter Gallios flow cytometer (Beckman Coulter, Miami, FL).

\section{Western blot analysis}

Western blot analysis was carried out to examine the expression of proteins involved in the apoptotic pathway. To perform this assay, 75,000 cells $/ \mathrm{mL}$ were seeded and treated with ST compounds $(10 \mathrm{nM}, 20 \mathrm{nM}, 40 \mathrm{nM}, 60$ $\mathrm{nM}, 80 \mathrm{nM}$ ) for $48 \mathrm{~h}$ and whole cell lysate was prepared using RIPA buffer (25 mM Tris-Cl pH 7.6, $150 \mathrm{mM}$ Sodium chloride, 1\% NP-40, 1\% Sodium deoxycholate, 1\% Sodium Dodecyl Sulphate, $1 \mathrm{mM}$ Phenylmethylsulphonyl fluoride, $1 \mathrm{mM}$ Sodium orthovanadate). Crude cell lysates $(30-40 \mu \mathrm{g})$ were electrophoresed on SDSPAGE (Sodium dodecyl sulfate-polyacrylamide gel electrophoresis) and were transferred on to Polyvinylidene fluoride membrane (Millipore, USA) to probe with respective antibodies. The primary antibodies against caspase 9, cleaved caspase 9, caspase 3, cleaved caspase 3 , caspase 8 and Horseradish peroxidase-labeled secondary anti-rabbit antibodies were purchased from Cell Signalling Technology, Beverly, MA. Anti-tubulin, AntiMMP1 and its secondary mouse antibody were purchased from Santa-Cruz Biotechnology, Santa Cruz, CA. The membrane was probed with appropriate antibodies and was developed using chemiluminescence reagent (Clarity Western ECL blotting substrate, Biorad). The blot image was captured by using a Syngene G: Box gel doc system. Protein band image quantification was done using GelQuant. Net, Biochem Lab solutions.

\section{Transwell migration assay}

Transwell assay was performed by seeding 75,000 cells/ $\mathrm{mL}$ in a 6-well plate and were allowed to grow for $24 \mathrm{~h}$. Forty and eighty nM ST08 treatment was done for $24 \mathrm{~h}$. Permeable migration chambers were purchased from Corning Inc. (24-well insert; pore size, $8 \mu \mathrm{m}$ ) and were coated with $75 \mu \mathrm{L}$ of matrigel and incubated at $37^{\circ} \mathrm{C}$ for $24 \mathrm{~h}$ for settling. Fifty thousand cells/ millilitre treated 
cells were suspended in $200 \mu \mathrm{L}$ media without FBS and added into the top chamber. Migration was allowed to occur for $5 \mathrm{~h}$ in a $\mathrm{CO}_{2}$ incubator. Then cells were fixed with $4 \%$ paraformaldehyde and stained with $2 \%$ crystal violet. Cells that did not migrate to lower compartment were cleaned using a cotton swab. Each insert was imaged in for five random fields at 10X magnification and analysis was done using NIH ImageJ software. Two independent experiments were carried out in duplicates.

\section{Statistical analysis}

Data from 3 different biological replicates were collected and values are expressed as Mean \pm SE in bar graphs. One-way or Two-way ANOVA followed by Tukey's multiple comparison test was carried out and significance is represented as $* * * *$ ( $p$-value $\leq 0.0001)$, $* * *$ ( $p$ value $\leq 0.001)$, ${ }^{* *}(p$-value $\leq 0.01),{ }^{*}(p$-value $\leq 0.05)$. Statistical analysis was done using GraphPad Prism 7 tool.

\section{Results}

\section{Characterization of ST03 and ST08}

ST03 (1,2-bis[(3E,5E)-3,5-bis[(2-chlorophenyl)methylene] -4-oxo-1-piperidyl]ethane-1,2-dione) and ST08 ([4-[(E) -[(5E)-1-[2-[(3E,5E)-3,5-bis[(4-hydroxyazonylphenyl)methylene]-4-oxo-1-piperidyl]-2-oxo-acetyl]-5-[(4-hydroxyazonylphenyl)methylene]-4-oxo-3-piperidylidene]methyl]phenyl] azinic acid) were prepared based on the procedure given above. The structures of the synthesized compounds were confirmed by IR, NMR, and Mass spectrometry. The vibration of $\mathrm{C}-\mathrm{H}$ bonds was observed between 3075 and $3003 \mathrm{~cm}^{-1}$ whereas for aliphatic $\mathrm{C}-\mathrm{H}$ bonds observed between 2946 and $2840 \mathrm{~cm}^{-1}$, and for $\mathrm{C}=\mathrm{O}$ bonds observed between 1666 and $1640 \mathrm{~cm}^{-1}$. In ${ }^{1} \mathrm{H}$ NMR, all the synthesized compounds showed prominent signals for aromatic and olefinic protons between $\delta$ 7.99-6.64 ppm. The structures of all the compounds were ensured by mass spectrometry. The detailed characterization results of the compounds are provided in the supplementary section (Additional file 1: Figures S1 and S2).

\section{ST03 and ST08 exert cytotoxicity on cancer cell lines with least effect on normal cells}

ST03 and ST08 compounds were examined for its cytotoxicity on a) leukemic cell lines: CEM, K562, Nalm6 b) ovarian cancer cell lines: PA1 and A2780 c) Breast cancer cell lines: MCF-7, MDA-MB-231 d) $293 \mathrm{~T}$ (normal kidney cell line) e) A431 (skin cancer cell line) f) HeLa (cervical cancer cell line) and also on g) PBMC (peripheral blood mononuclear cells) using MTT, LDH, and Trypan blue exclusion assays. In the pilot screening experiment, all cells were treated with five different concentrations ( $1 \mathrm{nM}$ to1 $\mu \mathrm{M}$ ) of compounds (ST03 and ST08) for 48 and $72 \mathrm{~h}$. Both the compound showed cytotoxicity at sub-micromolar concentrations. DMSO was used as the vehicle control. $\mathrm{IC}_{50}$ values of these compounds were calculated using all three methods and is listed in (Table 1 and 2).

Curcumin showed 50\% cytotoxicity in the range of $7-$ $10 \mu \mathrm{M}$, ST compounds were in $0.030-0.080 \mu \mathrm{M}$ range. Both, ST03 and ST08, showed $100 x$ higher potency than the parent compound curcumin. (Tables 1 and 2, Fig. 3c, Additional file 1: Table S1).

Since ST compounds exhibited cytotoxicity at nanomolar concentrations, the next series of cytotoxicity assays were carried out in a range of $1 \mathrm{nM}$ to $1000 \mathrm{nM}$ to calculate $\mathrm{IC}_{50}$. Initial experiments were carried out on leukemic cell lines (CEM, K562, and Nalm6) using trypan blue assay. Cells were treated with an equivalent amount of DMSO as vehicle control. Dose-Dependent induction of cell death was seen in ST03, and ST08 treated cells. The lowest concentration $(1 \mathrm{nM})$ was found to be least effective on all the cell lines tested (Fig. 2a). Nonetheless, at concentrations such as at $\sim 30-50 \mathrm{nM}$ onwards, we observed effective cytotoxicity, and 1000 $\mathrm{nM}$ showed maximum inhibition at $48 \mathrm{~h}$ and $72 \mathrm{~h}$ (Fig. $2 \mathrm{a})$. No cytotoxicity was observed with the vehicle control, DMSO (0.1\%). From these results, it was evident

Table 1 Structure of ST03 and IC $C_{50}$ values. IC $C_{50}$ values were calculated from the average $I_{50}$ of all cytotoxicity assays conducted on particular cell line at $48 \mathrm{~h}$, and the results are summarized in micromolar concentrations

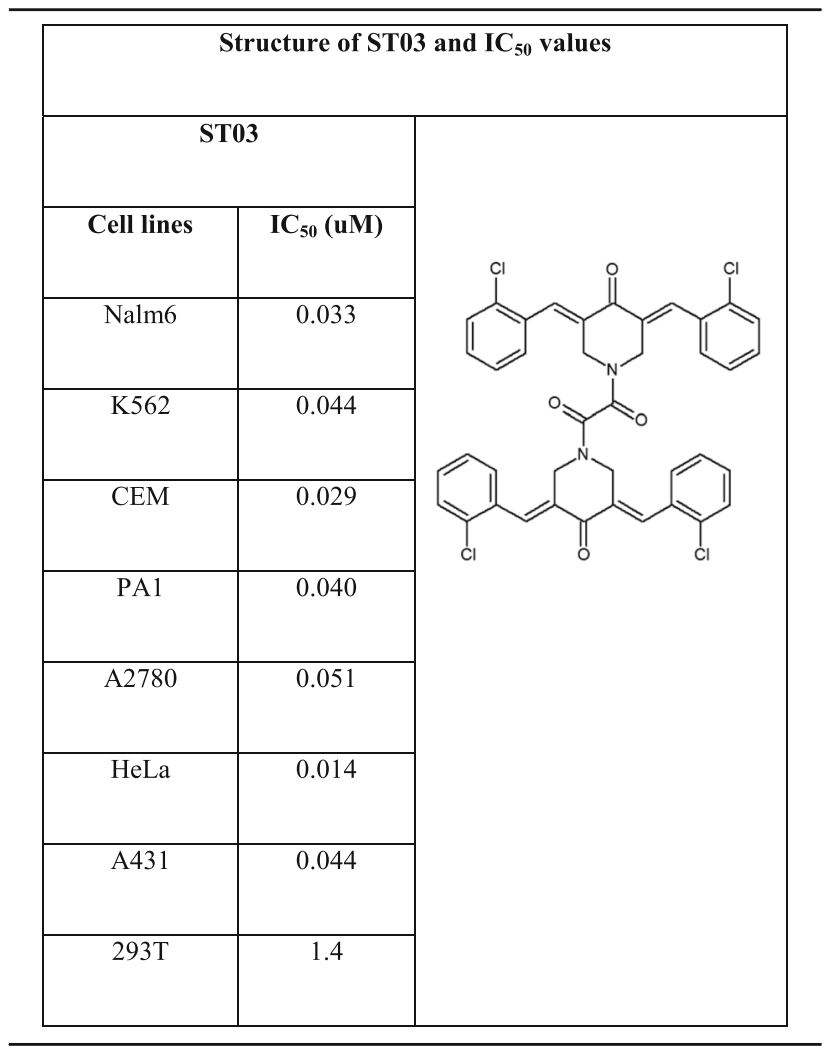


Table 2 Structure of ST08 and IC $C_{50}$ values. IC 50 values were calculated from the average $I_{50} S$ of all cytotoxicity assays conducted on particular cell line at $48 \mathrm{~h}$, and the results are summarized in micromolar concentrations

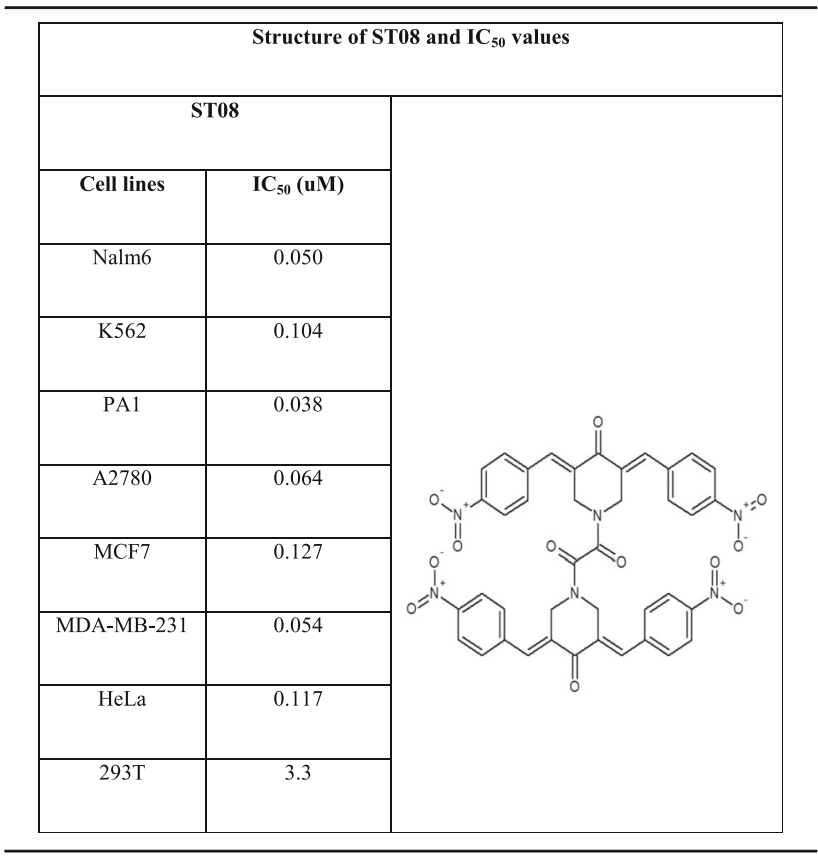

that ST03 and ST08 are toxic to human leukemic cell lines, and ST03 showed relatively higher potency than ST08. Peripheral blood mononuclear cells were used as normal cells to test cytotoxicity. The cells were treated with ST03 and ST08 for $48 \mathrm{~h}$ and cell viability assessed. No cytotoxicity was observed at doses three times more $(150 \mathrm{nM})$ than the effective dose on cancer cell lines ( 30-50 nM).

Additionally, MTT assay was also performed to check cytotoxicity in both liquid (CEM, K562) and solid cancer cell lines (PA1, A2780, A431, MDA-MB-231, MCF7, and $293 \mathrm{~T}$ (Fig. 3) following treatment with ST03 and ST08 for $48 \mathrm{~h}$ and $72 \mathrm{~h}$. The reduction of MTT by live-cell mitochondria was considered directly proportional to cell proliferation. A dose-dependent (Fig. 3), decrease in the cell viability was observed. Both the drugs showed IC50 in the range of $30-50 \mathrm{nM}$ in all the cell lines tested. Keeping our interest in developing drugs against metastatic ovarian and breast cancer, we tested, ST03, and ST08 induced cell death in (PA-1, ovarian teratocarcinoma vs. A2780, epithelial cancer). ST03 showed IC50 of $41 \mathrm{nM}$ in PA1 vs. $54 \mathrm{nM}$ in A2780 (Fig. 3a). Whereas, ST08 showed higher inhibition on PA1 $(\sim 38 \mathrm{nM})$ among the other cell lines tested (Fig. 3b). Among the breast cancer cell line MCF-7 (epithelial) and MDA-MB231 (metastatic), MDA-MB-231(54 nM) showed better cytotoxicity than MCF-7 (127 nM) upon ST08 treatment. ST03, and ST08 showed the least toxic effect on normal kidney cell lines $(293 \mathrm{~T})$ as expected. These results again confirmed that both the compounds are cytotoxic to cancer cell lines rather than on normal cells. We also performed MTT with curcumin and found its $\mathrm{IC}_{50}$ in most cell lines to be in the range of $\sim 10 \mathrm{uM}-100$ uM which is approximately 100 times more than ST03 and ST08 (Fig. 3c, Additional file 1: Table S1).

Also, LDH (lactate dehydrogenase) assay was conducted to confirm the above-observed results by examining the cell damage caused by ST03 and ST08 treatment. LDH is a cytosolic enzyme present in most of the eukaryotic cells. When the plasma membrane integrity is lost during the cell death process, it leaks out of the cell [34]. $\mathrm{LDH}$ reduces $\mathrm{NAD}^{+}$to $\mathrm{NADH}$ with the help of lactate, and reduced NADH catalyses the formation of red formazan from INT with the help of PMS in the assay system. Thus, the presence of cytosolic LDH leads to the formation of red-coloured formazan, which directly correlates to the live cells present in the assay system.

PA1, A2780, A431, HeLa (Fig. 4a) cells were treated with ST03 and MDA-MB-231, MCF7 and HeLa (Fig. 4b) were treated with ST08 for 48 and $72 \mathrm{~h}$ and checked for cytoplasmic LDH content in each treatment (Fig. 4). LDH assay showed better sensitivity than MTT upon ST03 and ST08 treatment on cancer cell lines. However, the inhibitory concentration of both the compounds was in the same range. Here, among the ovarian cell lines tested, ST03 showed a better effect on PA1 cells $(\sim 39$ $\mathrm{nM}$ ) which is an ovarian teratocarcinoma cell line than A2780 ( $49 \mathrm{nM})$ epithelial cancer of ovary (Fig. 4a). On the other hand, ST08 was more effective on the MDAMB-231 cell line $(\sim 53 \mathrm{nM})$ than MCF7, the other breast cancer cell line tested. Although MCF7 is also a breast cancer cell type, it showed relatively less effectiveness $(\sim$ $125 \mathrm{nM}$ ) when compared to the triple-negative breast cancer cell type, MDA-MB-231 (Fig. 4b).

\section{ST03 and ST08 induced apoptosis in ovarian and breast cancer cell lines}

Since our novel compounds ST03 and ST08 inhibited the cancer cell proliferation, we were interested in analyzing the mechanism by which the compounds induce cytotoxicity on ovarian and breast cancer cell lines. It is well known that anti-cancer compounds can cause different types of cell deaths such as apoptosis, necrosis or autophagy, thereby determining the fate of cell [35]. Thus, to dig into the causative mechanism, ovarian and breast cancer cells were treated with ST03 and ST08, subjected to flow cytometry analysis after staining with annexin V-FITC-PI staining [36]. In live cells, PS (phosphatidylserine) component of the plasma membrane is facing the cytoplasmic side. In a cell undergoing apoptosis, PS flips towards the outer side. This can be recognised by Annexin V. In cells undergoing cell death via 


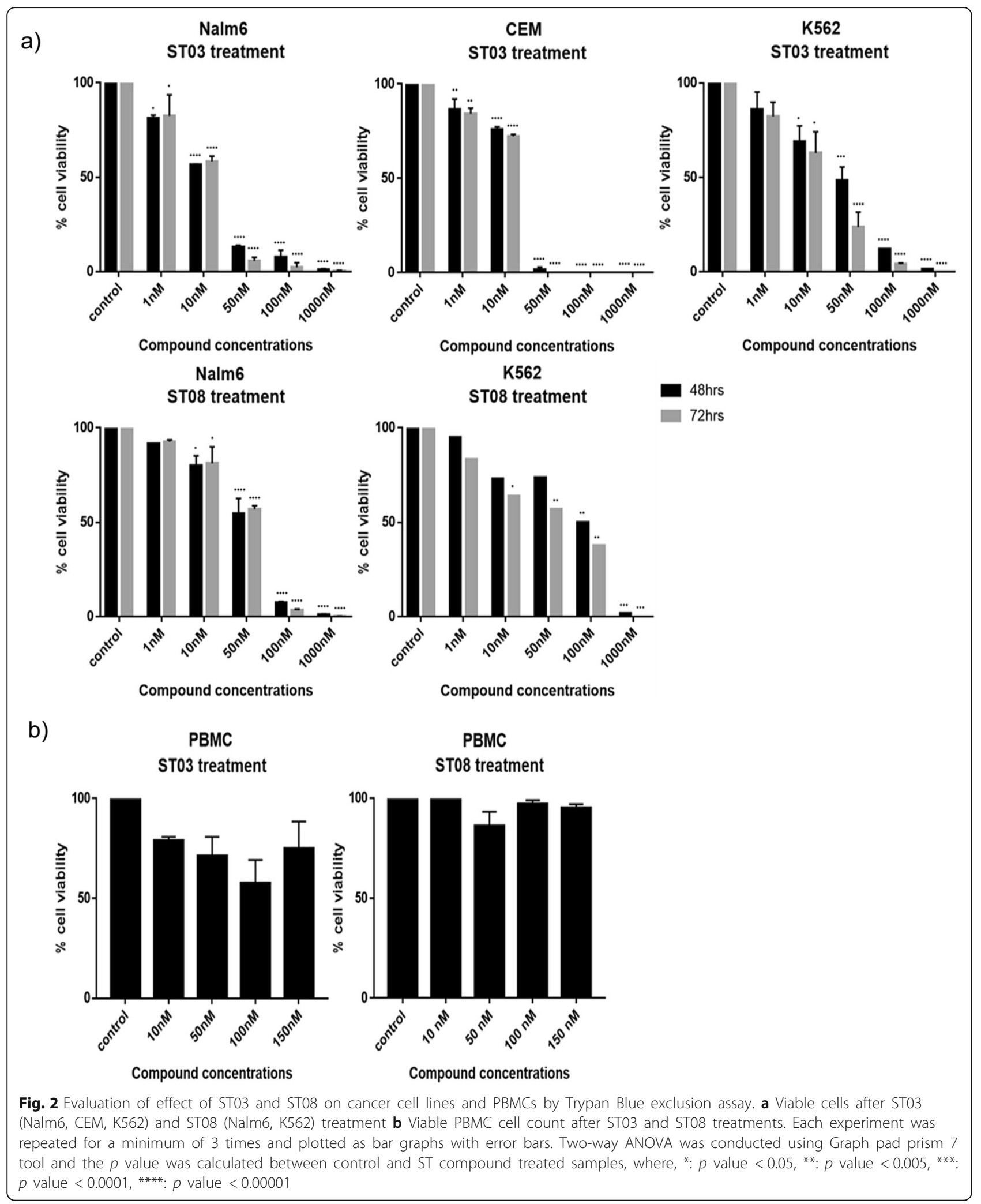


a)
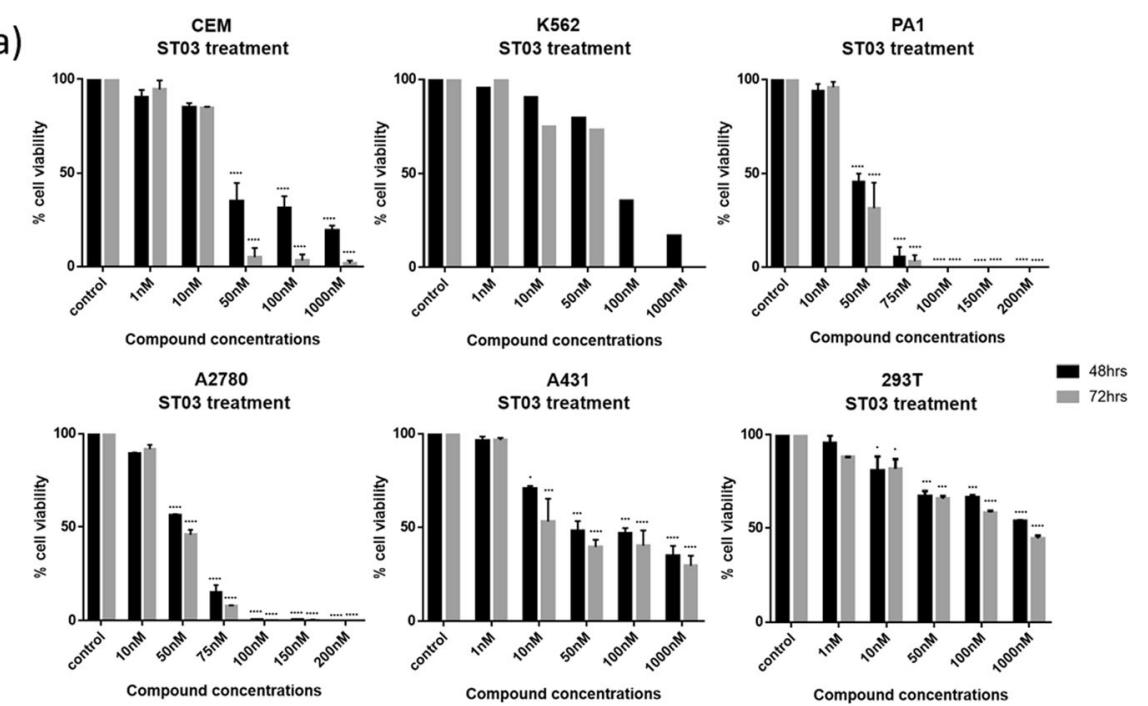

b)
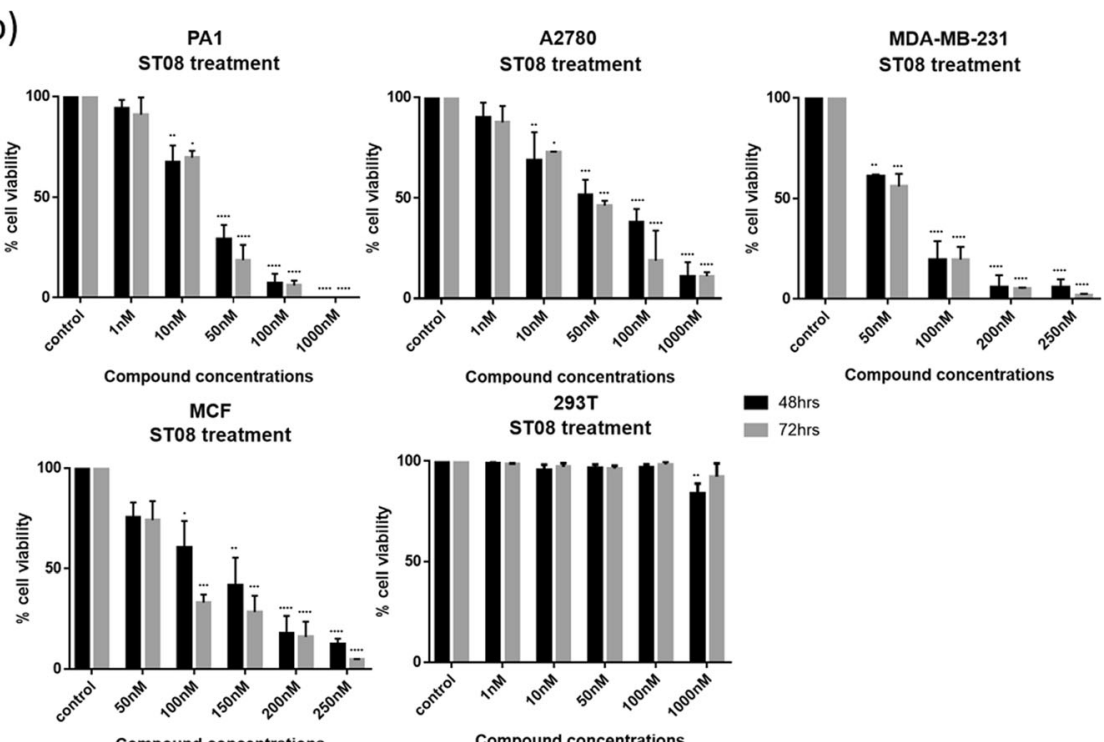

Compound concentrations $\begin{array}{cc}293 \mathrm{~T} & 48 \mathrm{hrs} \\ \text { ST08 treatment } & 72 \mathrm{hrs}\end{array}$
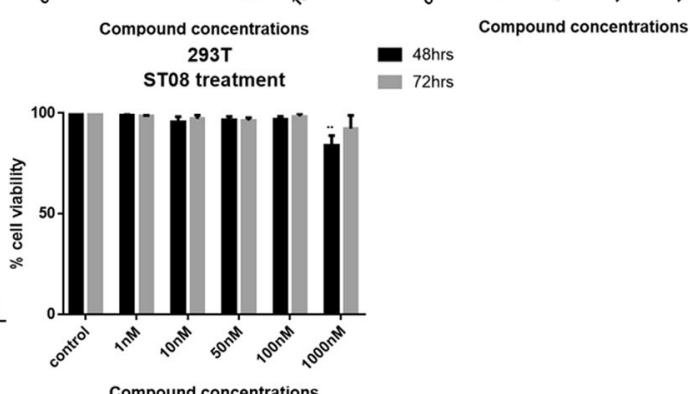

c)

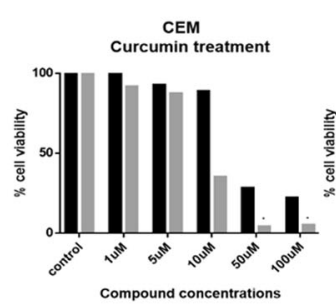

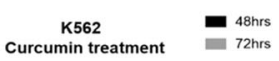
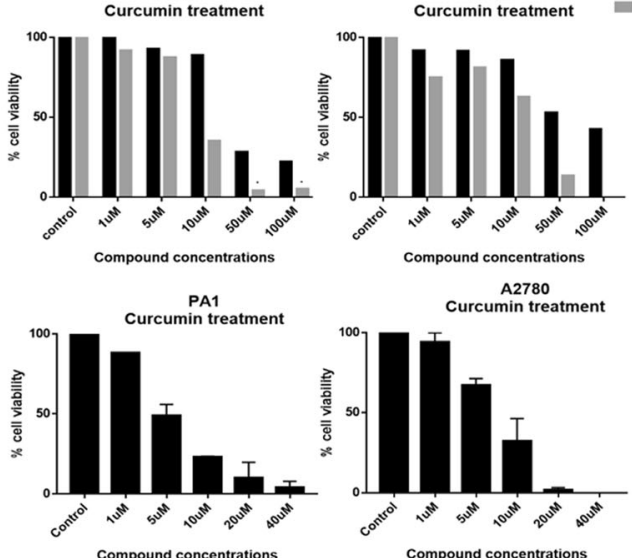

Fig. 3 (See legend on next page.) 
(See figure on previous page.)

Fig. 3 Evaluation of the effect of ST03, ST08 and curcumin compounds on cell lines by MTT assay. a ST03 treatment on PA1, A2780, K562,

CEM,A431 and 293 T. b ST08 treatment on PA1, A2780, MDA-MB-231, MCF-7 and 293 T. c Curcumin treatment on PA1, A2780, CEM and K562. Each experiment was repeated for a minimum of 3 times and plotted as bar graphs with error bars. Two-way ANOVA was conducted using Graph pad prism 7 tool and the $p$ value was calculated between control and compound treated groups, where, ${ }^{*}: p$ value $<0.05,{ }^{* *}: p$ value $<$ $0.005,{ }^{* * *}: p$ value $<0.0001,{ }^{* * * *}: p$ value $<0.00001$

necrosis, PS is not flipped, but cells are leaky; therefore, PI enters the nuclei and stains DNA. Annexin V, together with Propidium iodide (PI) is used for the detection of apoptotic cell population based on the integrity of the plasma membrane. The dot blots obtained from flow cytometry analysis shown in Fig. 5 describes the population of cells at different stages of cell death. The lower left quadrant contains cells that are live, negative for both the stains (Annexin ${ }^{(-)}$PI ${ }^{(-)}$), lower right quadrant is occupied by early apoptotic cells (Annexin ${ }^{(+)}$PI $\left.{ }^{(-)}\right)$, upper right quadrant contains late apoptotic cells $\left(\right.$ Annexin ${ }^{(+)} \mathrm{PI}{ }^{(+)}$) and the upper left quadrant has necrotic/dead cells (Annexin ${ }^{(-)} \mathrm{PI}^{(+)}$). The results shown in Fig. 5a-d depict that, both ST03 and ST08 induce a greater extent of apoptotic cell death in ovarian and breast cancer cell lines, respectively.

The representative dot plot shows that the $50 \mathrm{nM}$ concentration of ST03 could induce $47.8 \%$ of cells death, in which $25.9 \%$ were early apoptotic (Annexin ${ }^{(+)}$PI ${ }^{(-)}$), $19.3 \%$ were late apoptotic $\left(\right.$ Annexin $\left.{ }^{(+)} \mathrm{PI}^{(+)}\right), 2.6 \%$ were necrotic (Annexin ${ }^{(-)} \mathrm{PI}^{(+)}$) in PA1 (Fig. 5a, b). Maximal accumulation of early apoptotic population $(16.2 \%)$ was seen at $40 \mathrm{nM}$ of ST08 on breast cancer cell line MDAMB-231. And at $80 \mathrm{nM}$, these early populations have migrated to the third compartment, leaving $29.7 \%$ unstained, $6.9 \%$ in early, $55.7 \%$ in late and $3.2 \%$ in necrotic stages (Fig. 5c, d). From these results, it is evident that both compounds exhibited cell death via apoptosis.

\section{ST03 and ST08 induce the intrinsic apoptotic pathway in breast and ovarian cancer cell lines}

As we observed apoptotic populations in the treated cells from annexin V-FITC/PI assay results; we were curious to know the pathway of apoptosis. Thus, to further investigate the cell death pathway (intrinsic vs extrinsic pathway of apoptosis) induced by ST03 and ST08, we checked the expression of key proteins involved in apoptotic pathways using western blotting. Caspase-9 is an initiator caspase which is a part of mitochondria-mediated intrinsic apoptotic pathway and is activated by cytochrome-c released from mitochondria. At the same time, caspase-3, being the executioner caspase, is responsible for the proteolysis of $\alpha$-fodrin, PARP, gelsolin, ICAD and other caspases leading to the effective completion of apoptosis process [37, 38]. In our treatments, both the compounds significantly increased the amount of cleaved/active caspase 9 and cleaved/ active caspase 3 in PA1 and MDA-MB-231 cancer cell lines Fig. 6a-b. On the other hand, the extrinsic apoptotic marker procaspase 8 and its active form were found to be downregulated. Both ST03 and ST08 induce the intrinsic apoptotic pathway in ovarian cancer cell line PA1 and in breast cancer cell line MDA-MB-231.

\section{ST08 inhibits breast cancer cell migration}

The effect of ST08 on the migratory ability of MDAMB-231 was evaluated by Transwell migration assay. Compared with untreated control cells, the migration capacity of the $24 \mathrm{~h}$ treated cells was significantly diminished (Fig. 7a, b). The migration inhibition rate was 3 fold in the treated cells (Fig. 7b) when compared to the untreated control groups. Besides, we examined the expression of MMP1 (Fig. 7c) in the ST08 treated MDAMB-231 cells. Interestingly, MMP1 showed reduced expression at higher concentrations $(80 \mathrm{nM})$ of ST08. Cell migration is the most important event that happens as an initial step of metastasis [39]. This result indicates that ST08 can inhibit the cancer cell migration effectively, which can prevent metastasis and progression of cancer.

\section{Discussion}

Drug toxicity and disease relapse remain as major hurdles in the management of cancer despite having advanced targeted therapies. Plant-derived low toxic phenolic compounds are known to exhibit anti-cancer activity by inducing apoptosis in cancer cells [27, 40, 41]. Curcumin is one such example which exhibits anticancer activity against various cancer types [42-47]. Curcumin has been replaced by more potent and bioavailable derivatives, which have attracted attention for the development of novel drugs [48]. The novel curcumin derivatives developed in this study has exhibited remarkable cytotoxicity $(\sim 100 \mathrm{X})$ better than parent compound at nanomolar concentrations on a wide range of cancer cell lines which includes both representative liquid and solid tumour cell lines. Various types of curcumin derivatives have been reported, to overcome the low potency, poor bioavailability and side effects demonstrated by the parent compound curcumin [49]. One among them is 1,2-bis[(3E,5E)-3,5-dibenzylidene-4-oxo1-piperidyl]ethane-1,2-diones, which exhibited anticancer activity on variety of cancer cell lines [27-29]. Our novel compounds ST08 and ST03 synthesised from 


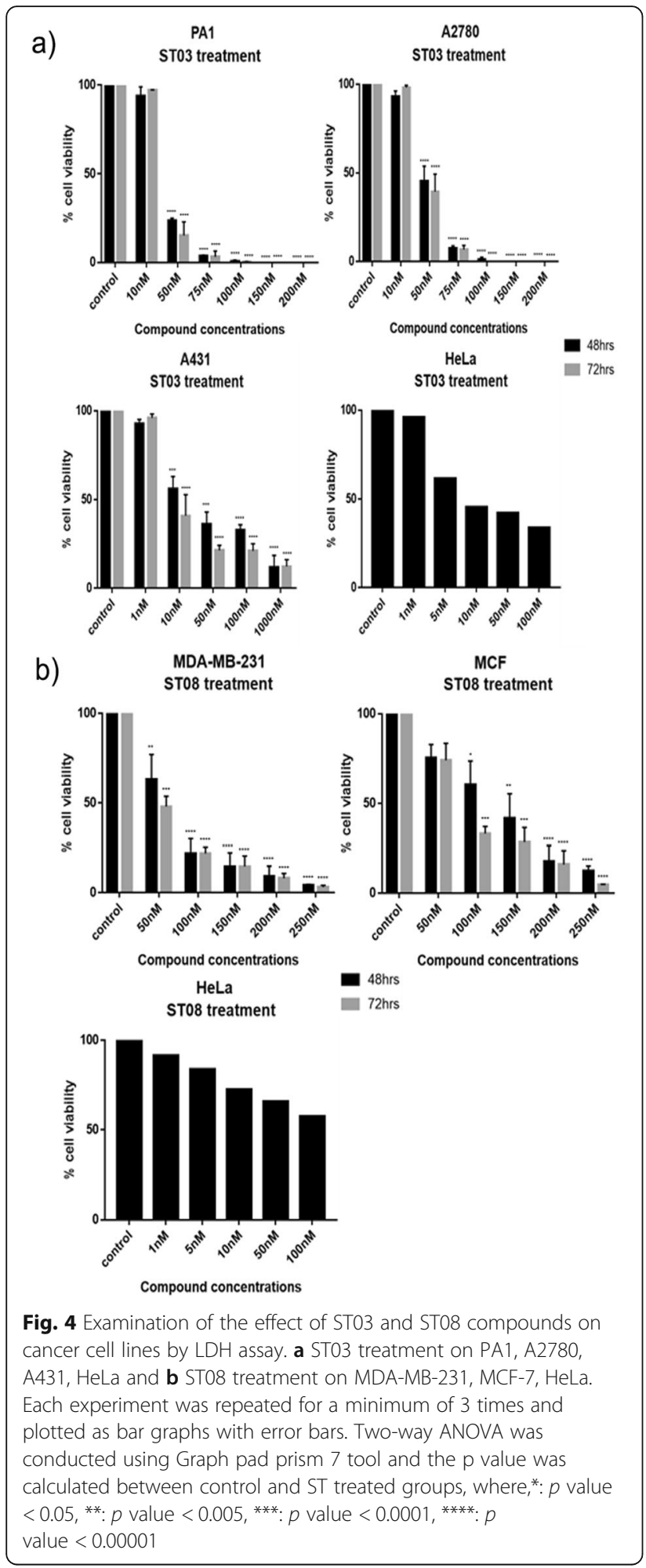

1,2-bis[(3E,5E)-3,5-dibenzylidene-4-oxo-1-piperidy-

1]ethane-1,2-dione, by adding strong electronwithdrawing groups such as $\mathrm{NO}_{2}$ and $\mathrm{Cl}$ - respectively to the backbone, has enhanced the anti-proliferative effect on the cancer cells particularly on ovarian cells (PA1) with stem cell-like properties. The cytotoxicity assays performed showed inhibition of cell growth by ST03 and ST08 in the range of $30-125 \mathrm{nM}$ in both adherent and non- adherent cell lines which is $\sim 100$ fold better than the parent compound curcumin, which was effective in the range of $\sim 10-100 \mu \mathrm{M}$ on most of the cancer cells lines reported till date $[43,44,50]$. ST03 and ST08 are stable and bioavailable better than Curcumin (data not shown).

Further analysis showed that ST03 was consistent in its effect among all cell lines tested with an average $\mathrm{IC}_{50}$ value of $\sim 36 \mathrm{nM}$. Among the ovarian cancer cell lines, PA-1 (teratocarcinoma, undifferentiated) and A2780 (epithelial cancer cell line, differentiated), ST03 showed the better effect on PA1 cells $(41 \mathrm{nM})$ as compared to A2780 (54 nM). Similarly, ST08 was found to show differential cytotoxicity with PA1 $(38 \mathrm{nM})$ better than A2780 (64 nM). Since ovarian cancer cell lines showed promising results, we checked the effect of ST08 on breast cancer cell lines. We took MDA-MB231 (triple negative, basal, metastatic) and MCF-7 (epithelial, luminal) for the comparison. As observed in the ovarian cancer cell line, the highly metastatic MDA-MB231 showed better cytotoxicity $(54 \mathrm{nM})$ than MCF-7 (127 $\mathrm{nM})$. It is to be noted that, ST03 and ST08 showed cytotoxicity on undifferentiated cancer cells populations which have the potency to migrate (metastatic) and differentiate (stem cell characteristics). A comparison of the $\mathrm{IC}_{50}$ value of both the ST compounds has revealed the peculiar characteristics of them on the MDA-MB231 and PA1 cell lines tested. It showed that these novel compounds are highly potent on PA1 and MDA-MB231 cell lines (Table 1 and 2), which possess some of the properties of undifferentiated cells [51-54].

PA1 belongs to the category of teratocarcinoma, where the tumour cells have originated from germLine cells which have the characteristics of stem cells [52]. For instance, although we observe reasonable response rates to first-line chemotherapy, recurrence with resistance occurs in most of the cases of ovarian cancer, which is delivered by cancer stem cells that remain even after treatment $[55,56]$. It is known that cancer stem cells expansion and characteristics lead to drug resistance [57, 58]. For the improved treatment outcome without relapse, it is necessary to eliminate cancer stem cells. The new treatment strategies of ovarian cancer are thus looking for drugs that can remove cancer stem cells very effectively. Drugs such as AS602801, and 673A has proved to eradicate ovarian cancer stem cells, and it increased the sensitivity of cancer stem cells to standard drugs such as cisplatin and paclitaxel $[59,60]$. When compared to the potency of these drugs, ST03 showed cytotoxicity at a nanomolar concentration in PA1 cells (undifferentiated stem cell-like) in vitro. Thus the likelihood of 
a)
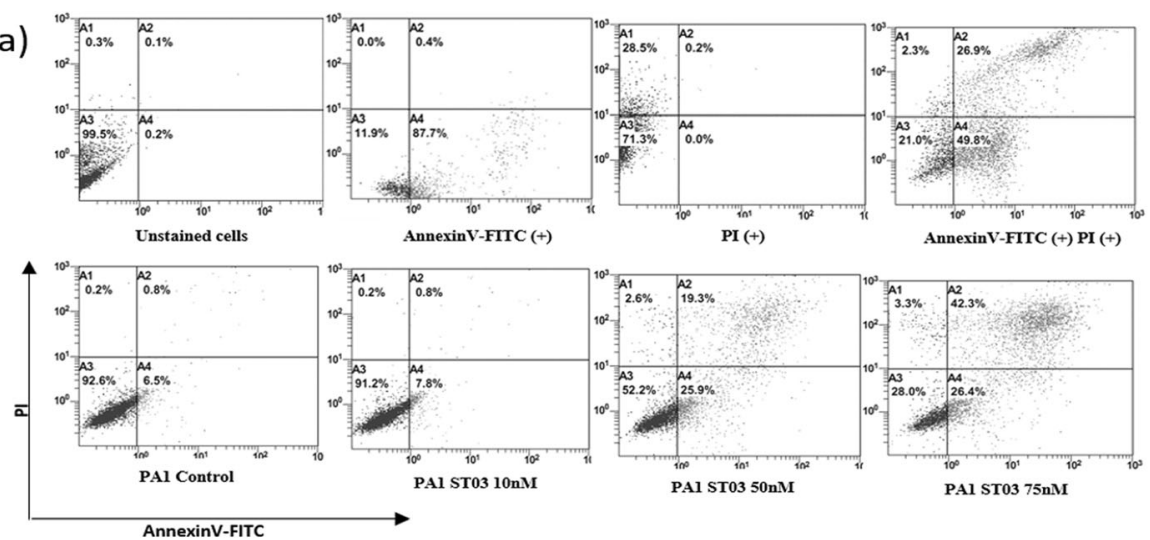

b)

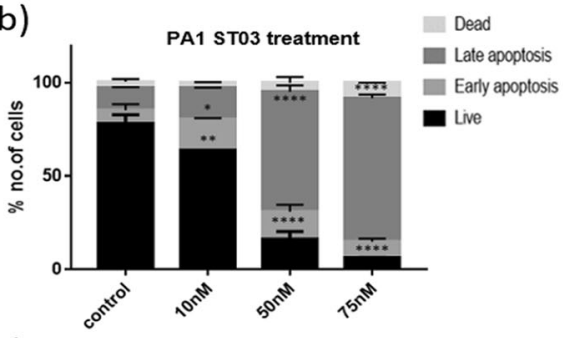

c)

Compound concentrations
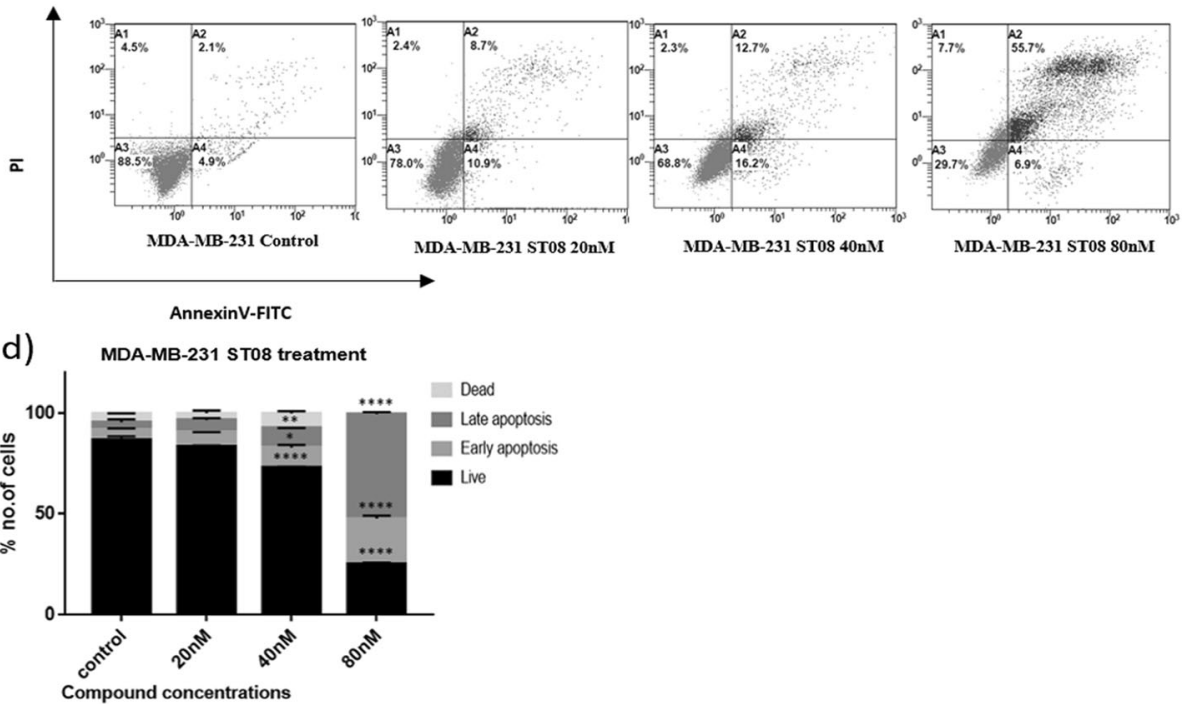

Fig. 5 Evaluation of cell death by ST compound treatments using AnnexinV-FITC/PI. a ST03 treated PA1 cells stained with Annexin/FITC-PI and $\mathbf{b}$ Quantification of percentage of cells in each stage c ST08 treated MDA-MB-231 cells stained with Annexin/FITC-PI and d) Quantification of cells in each stage. Each experiment was repeated for a minimum of 3 times and plotted as bar graphs with error bars. Two-way ANOVA was conducted and the $p$ value was calculated between control and ST03 treated groups, where, ${ }^{*}$ : $p$ value $<0.05,{ }^{* *}$ : $p$ value $<0.005,{ }^{* * *}$ : $p$ value $<0.0001,{ }^{* * * *}$ : $p$ value $<0.00001$

improvement in anti-cancer activity cannot be ruled out if ST03 and ST08 are used in combination with standard of care drugs. Owing to the fact that ovarian cancer stem cells are relatively challenging to eradicate, the observed cytotoxicity of ST03 on PA1 is promising.

In the case of epithelial ovarian cancer cell line A2780, the effect of ST compounds were observed at a little higher concentration than on PA1. This observation is crucial as it indicates the differential cytotoxicity of ST compounds on tumors of different origin. Differential sensitivity of cell lines to ST compounds would help in understanding drug metabolism in cell types and thereby help to combat the acquired resistance. This knowledge would ultimately help in deciding combination therapies [61] . 
a)
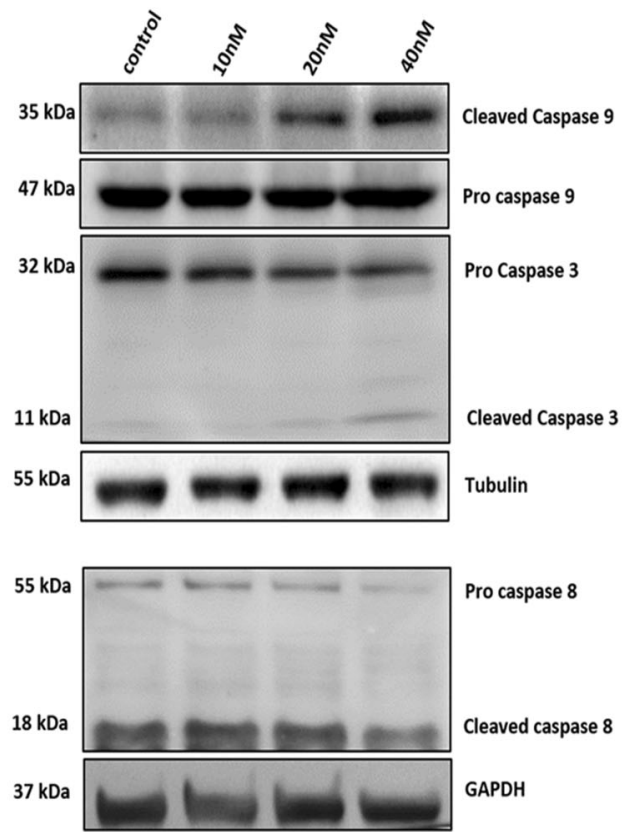

b)

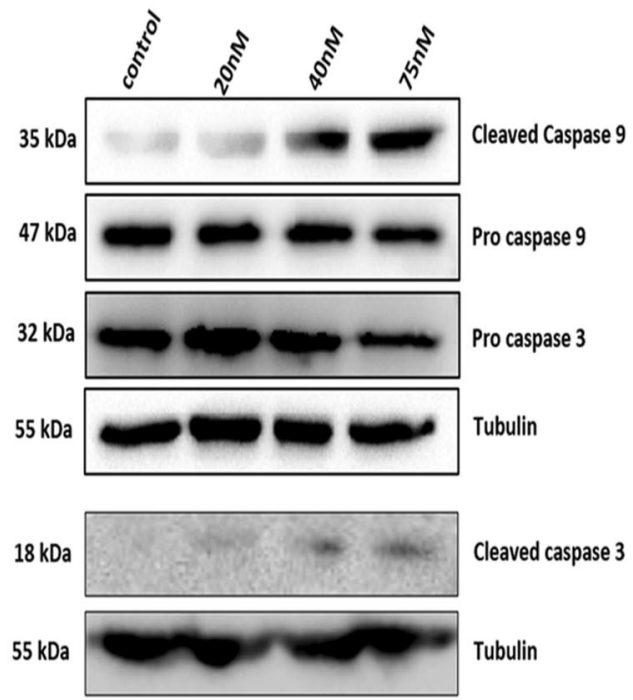

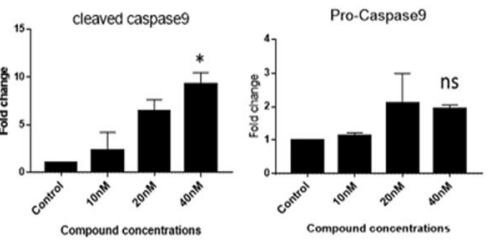
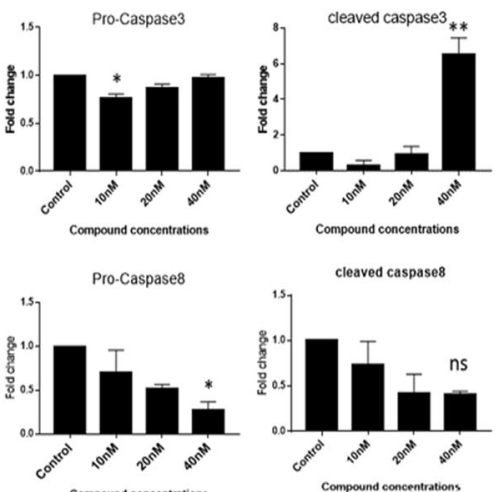
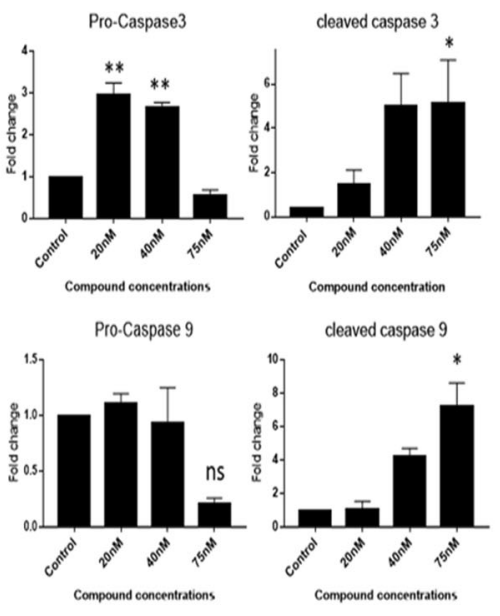

Fig. 6 Expression of apoptotic proteins PA1 and MDA-MB-231 cells on compound treatment. a Western blot image of PA1 cell lysate treated with ST03 compound for $48 \mathrm{~h}$ b Western blot image of MDA-MB-231 cell lysate treated with ST08 compound for $48 \mathrm{~h}$. Each experiment was repeated for a minimum of 3 times and plotted as bar graphs with error bars. One way ANOVA was conducted and the $p$ value was calculated between control and ST03 treated groups, where, ${ }^{*}: p$ value $<0.05,{ }^{* *}: p$ value $<0.005$

Lack of multiple receptors is the major characteristics of the triple-negative breast cancer cell line MDA-MB$231[62]$ and these cells respond the least to hormone therapies [63]. As a reason, potent inhibitors derived from natural compounds that can kill triple-negative breast cancer cells were developed in our laboratory. The effectiveness was predominant on MDA-MB-231, the triple-negative breast (highly metastatic) cancer cell line $[39,64-66]$ than on the non-metastatic cell line MCF7. This result is very promising since the triplenegative breast cancer types are highly metastatic and difficult to treat, as there are a fewer treatment strategy for triple-negative breast cancer types [67].

To study the selectivity of ST03 and ST08 between cancer and normal, peripheral blood mononuclear cells and $293 \mathrm{~T}$ cell lines were used. It was found that ST03 $(>150 \mathrm{nM})$ and ST08 (>150 nM) are not cytotoxic to them at concentrations, at which it was cytotoxic to the non- adherent cancer cell lines. This points onto a fascinating fact that, these compounds are selective towards cancer cells and are less effective on normal cells which would render less systemic toxicity. 


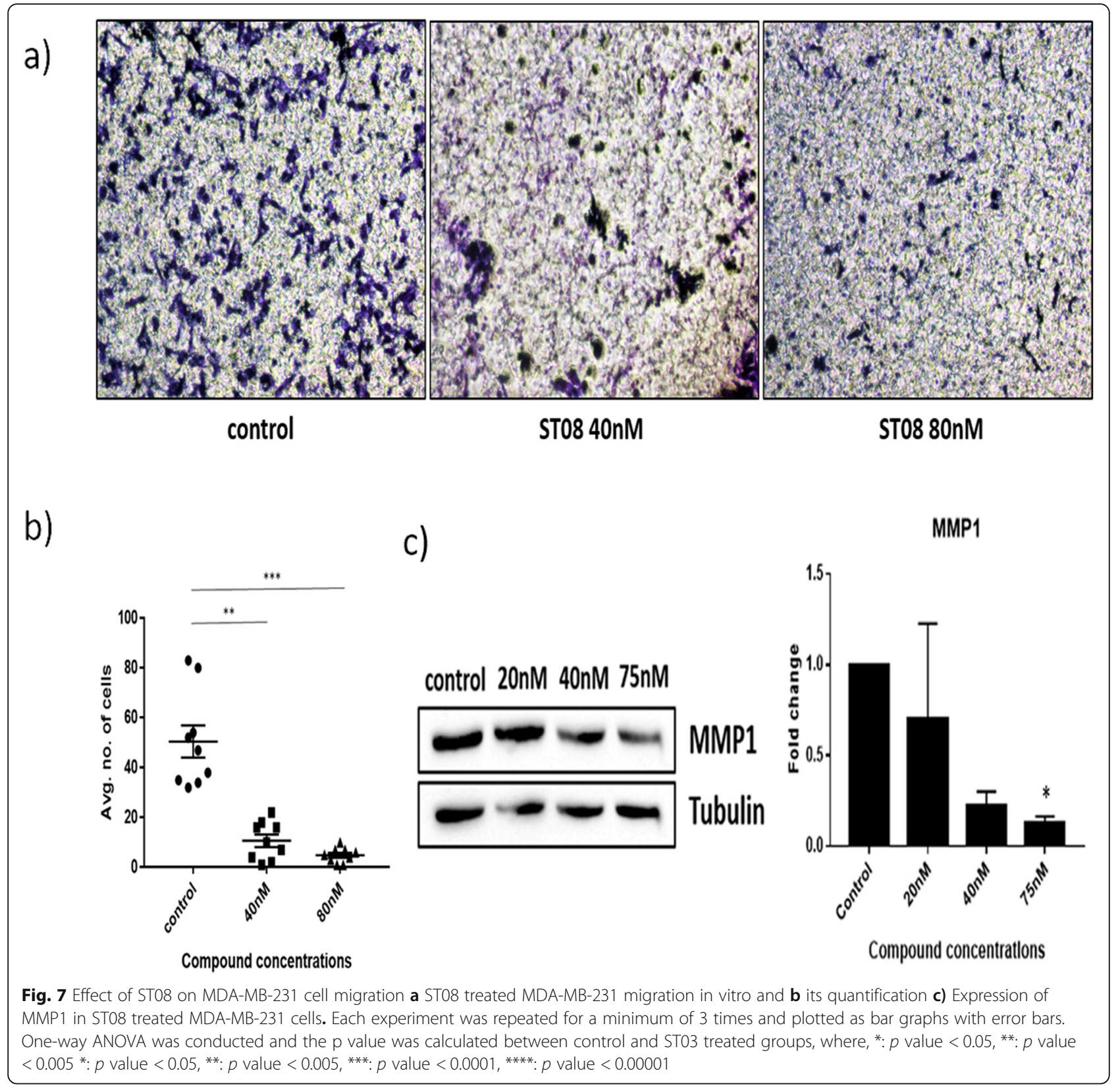

Metastasis is the primary cause of high mortality rate seen in cancer patients [68] which justifies the requirement of drugs with migrastatic potential. Previous reports have established the migrastatic property of curcumin [69] in cancer cells. Metastatic cell types undergo EMT (Epithelial to mesenchymal transition) during metastasis [70]. EMT also occurs not only in metastasis but also during wound healing and helps in tissue regeneration [70]. Recently, reports have linked EMT and dedifferentiated cancer stem cell-like properties of cancer cells. This points out the fact that cancer cells when they undergo EMT transition, it also acquire cancer stem cell-like features which initiates metastasis
$[71,72]$. The anti-cancer agent which targets the metastatic cancer cells can restrain the cancer stem cell-like cells or vice versa. Our study has demonstrated the cytotoxic effect of ST compounds on both liquid and solid cancer types, including stem cell-like PA1 and highly metastatic MDA-MB-231. This observation made us hypothesise the anti-metastatic potential of ST compounds.

Interestingly, we observed anti-metastatic property of ST08 compound on the highly aggressive, triplenegative, metastatic, MDA-MB-231 cell line. There was 4-5 fold reduction observed in migration of the MDAMB-231 cells upon ST08 treatment. In addition, MMP1, 
the matrix metalloprotease reported to be one of the key players in breast cancer cell metastasis [73], was also found to be downregulated on ST08 treatment. Our results are in agreement with the characteristics of parent compound curcumin which also can block metastasis of cancer cells. Hence, our results report for the first time that ST compounds can suppress cancer cells possessing metastatic and cancer stem cell-like properties in vitro. These characteristics of our compounds might, therefore, open up a new strategy for treating recurrent malignant cancer types.

For the elimination of old cells and the growth of new cells, tightly regulated apoptosis process is required, and it plays a vital role in the growth and development of an organism [74]. Deregulation of apoptosis in a group of cells leads to proliferation of cells, cancer. Anti-cancer drugs such as platinum compounds and taxanes usually induce apoptosis in cancer cells [75]. Here in our study, we observed early and late apoptotic events in both the treatments. Further, there are majorly two types of apoptosis, mitochondrial-mediated intrinsic and death receptor-mediated extrinsic [76, 77]. Our results demonstrated that both the compounds are inducing cell death via intrinsic apoptosis as there is an upregulation in the expression of caspases such as caspase 3 and caspase-9. Caspases such as caspase- 9 and caspase- 3 are predominant proteins involved in the process of the intrinsic apoptotic pathway. A cascade activation of these molecules results in activation of PARP, cleavage of cytoskeleton proteins and chromatin fragmentation leading to apoptosis $[78,79]$. We observed an increase in the expression of a cleaved form of caspase- 9 in both the cell lines treated with ST03 or ST08. In the PA1 cell line, ST03 treatment has increased the expression of cleaved caspase- 3 and caspase- 9 indicative of the intrinsic pathway of apoptosis. Similarly increase in cleaved caspase- 9 and caspase- 3 was indicative of intrinsic pathway of apoptosis in ST08 treated MDA-MB-231.

The in vitro experiments conducted here, demonstrate the effective anti-cancer property of our novel curcumin derivatives ST03 and ST08. The compounds were found to be $\sim 100$ fold more potent than its parent compound, curcumin on both solid and liquid tumour types. The fascinating fact here is that they exhibited higher toxicity on cancer cell lines such as PA1 and MDA-MB-231, which possess cancer stem cell-like property to differentiate and migrate. The reduced expression of MMP1 and inhibition of migration on ST08 treatment indicate that this compound can modulate metastasis by inhibiting migration of cancer cells. Eradication of cancer stem cells and inhibition of metastasis could effectively reduce cancer recurrence and drug resistance which is a major hurdle in the cancer treatment. Hence, our results suggest that ST03 and ST08 can be considered as a promising candidate anticancer drug that can target both cancer stem cells and metastatic cells mostly responsible for the failure of cancer therapy. Further studies are required to understand the mechanism of cytotoxicity of these compounds, which is in progress.

\section{Conclusion}

We report for the first time two novel compounds, ST03 and ST08, which exhibit anti-cancer activity on both liquid and solid cancer types. These are $\sim 100$ fold better than its parent compound curcumin. We also show that these compounds inhibit cell proliferation by inducing intrinsic apoptosis and also suppressing cell migration in vitro. Due to the anti-cancer and migrastatic effect of ST03 and ST08 on stem cell-like ovary and breast cancer cell lines. These compounds have the potential to be developed as a novel anticancer agent towards the treatment of the metastatic, invasive, and recurrent cancer types.

\section{Supplementary information}

Supplementary information accompanies this paper at https://doi.org/10 1186/s12906-019-2685-3.

Additional file 1: Table S1. Curcumin structure and IC50 values. Figure S1. Mass spectrometry data. Figure S2. ${ }^{1}$ HNMR data.

\section{Abbreviations}

CDCl3: Deuterated chloroform; DAP: Diarylidenyl-piperidone;

DMSO: Dimethyl sulphoxide; ELISA: Enzyme-linked immunosorbent assay; FITC/PI: Fluorescein isothiocyanate/Propidium iodide; IR: Infrared; LDH: Lactate dehydrogenase; MP: Melting Point; MS (ESI): Mass spec (Electron Spray Ionisation); MTT: 3-(4,5-dimethylthiazol-2-yl)-2,5-diphenyltetrazolium bromide; NMR: Nuclear Magnetic resonance; Rf: Retardation factor

\section{Acknowledgements}

We thank Dr. Venketesh from SSIHL, Puttaparthi for help with Mass Spec. We would like to acknowledge Anjana Elizabeth Jose and Hassan. A. Swarup for assistance with NMR analysis, Meghana Manjunath, Dr. Raksha Rao K and Suran $\mathrm{R}$ Nambeesan in manuscript reading.

\section{Authors' contributions}

JK \& BC conceived the idea, designed the experiments, analysed the data and wrote the manuscript. JK, SN, VG and RM performed the experiments. ST, SK, SSK synthesised and provided the compound. All authors reviewed the manuscript. All authors read and approved the final manuscript.

\section{Funding}

We greatly thank the support by Department of Information Technology, Biotechnology and Science \& Technology, Govt. of Karnataka, India and Department of Science and Technology (SR/FST/LSI-536/2012), India for infrastructure grant, which helped in the design of the study, collection, analysis, and interpretation of data and in writing the manuscript. JK was supported by University Grants Commission (Sr. No. 2121330491, Ref. no. 22/ 12/2013 (ii) EU-V) Govt. of India, India SN by Department of Science and Technology-Innovation in Science Pursuit for Inspired Research (Ref. no. IF140949/2015), Govt. of India, India) and VG by Council of Scientific and Industrial Research (Ref. No. 09/1086/0002/2 K15/EMR-I) Govt. of India, India.

\section{Availability of data and materials}

Raw data used in this study and presenting tables and figures is sufficient to state that all data is contained within the manuscript and additional files. 


\section{Ethics approval and consent to participate}

This article doesn't contain any studies with human participants or animals.

\section{Consent for publication}

Not applicable.

\section{Competing interests}

The authors declare that they have no competing interests.

\section{Author details}

'Institute of Bioinformatics and Applied Biotechnology, Electronic City Phase 1, Bangalore, Karnataka 560100, India. ${ }^{2} \mathrm{JK}, \mathrm{SN}$, and VG are graduate students registered under Manipal Academy of Higher Education, Manipal 576104, India. ${ }^{3}$ Department of Biochemistry, Indian Institute of Science, Bangalore 560012, India. ${ }^{4}$ Department of Pharmaceutical Chemistry, KLE Academy of Higher Education and Research, KLE College of Pharmacy, Rajajinagar, Bangalore, KN, India.

Received: 8 March 2019 Accepted: 13 September 2019

Published online: 21 October 2019

\section{References}

1. Amin ARMR, Karpowicz PA, Carey TE, Arbiser J, Nahta R, Chen ZG, et al. Evasion of anti-growth signaling: a key step in tumorigenesis and potential target for treatment and prophylaxis by natural compounds. Semin Cancer Biol. 2015;35:S55-S77.

2. Hanahan D, Weinberg RA. The hallmarks of cancer. Cell. 2000;100:57-70.

3. Arruebo M, Vilaboa N, Sáez-Gutierrez B, Lambea J, Tres A, Valladares M, et al. Assessment of the evolution of cancer treatment therapies. Cancers. 2011;3: 3279-330.

4. Urruticoechea A, Alemany R, Balart J, Villanueva A, Vinals F, Capella G. Recent advances in cancer therapy: an overview. Curr Pharm Des. 2010;16:3-10

5. Prieto-Vila M, Takahashi RU, Usuba W, Kohama I, Ochiya T. Drug resistance driven by cancer stem cells and their niche. Int J Mol Sci. 2017;18:2574.

6. Chen $\mathrm{K}$, Huang $\mathrm{YH}$, Chen JL. Understanding and targeting cancer stem cells: therapeutic implications and challenges. Acta Pharmacol Sin. 2013; 34:732-40.

7. Torquato HF, Goettert MI, Justo GZ, Paredes-Gamero EJ. Anti-cancer Phytometabolites targeting cancer stem cells. Curr Genomics. 2017;18: 156-74.

8. Bachmeier BE, Killian PH, Melchart D. The role of curcumin in prevention and management of metastatic disease. Int J Mol Sci. 2018;19:1716.

9. Gandalovičová A, Rosel D, Fernandes M, Veselý P, Heneberg P, Čermák V, et al. Migrastatics - anti-metastatic and anti-invasion drugs: promises and challenges. Trends Cancer. 2017;3:391-406.

10. Deng Y, Verron E, Rohanizadeh R. Molecular mechanisms of anti-metastatic activity of curcumin. Anticancer Res. 2016;36:5639-47.

11. Gupta AP, Khan S, Manzoor MM, Yadav AK, Sharma G, Anand R, et al. Anticancer curcumin: natural analogues and structure-activity relationship. In: Studies in natural products chemistry, vol. 54; 2017. p. 355-401.

12. Fadus MC, Lau C, Bikhchandani J, Lynch HT. Curcumin: an age-old antiinflammatory and anti-neoplastic agent. J Tradit Complement Med. 2017:7:339-46.

13. Perrone D, Ardito F, Giannatempo G, Dioguardi M, Troiano G, Lo Russo L, et al. Biological and therapeutic activities, and anticancer properties of curcumin (review). Exp Ther Med. 2015;10:1615-23.

14. Reddy RC, Vatsala PG, Keshamouni VG, Padmanaban G, Rangarajan PN Curcumin for malaria therapy. Biochem Biophys Res Commun. 2005; 326:472-4.

15. Xu YX, Pindolia KR, Janakiraman N, Noth CJ, Chapman RA, Gautam SC. Curcumin, a compound with anti-inflammatory and anti-oxidant properties, down-regulates chemokine expression in bone marrow stromal cells. Exp Hematol. 1997;25:413-22.

16. Li Y, Zhang T. Targeting cancer stem cells by curcumin and clinical applications. Cancer Lett. 2014;346:197-205.

17. Zang S, Liu T, Shi J, Qiao L. Curcumin: a promising agent targeting cancer stem cells. Curr Med Chem Anticancer Agents. 2014;14:787-92.

18. Anand P, Kunnumakkara AB, Newman RA, Aggarwal BB. Bioavailability of curcumin : problems and promises. Mol Pharm. 2007;4:807-18.
19. Kálai T, Kuppusamy ML, Balog M, Selvendiran K, Rivera BK, Kuppusamy P, et al. Synthesis of N-substituted 3,5-bis (arylidene)-4-piperidones with high antitumor and antioxidant activity. J Med Chem. 2011;54:5414-21.

20. Selvendiran K, Ahmed S, Dayton A, Kuppusamy ML, Tazi M, Bratasz A, et al. Safe and targeted anticancer efficacy of a novel class of antioxidantconjugated difluorodiarylidenyl piperidones: differential cytotoxicity in healthy and cancer cells. Free Radic Biol Med. 2010;48:1228-35.

21. Terlikowska KM, Witkowska AM, Zujko ME, Dobrzycka B, Terlikowski SJ, Potential application of curcumin and its analogues in the treatment strategy of patients with primary epithelial ovarian cancer. Int J Mol Sci. 2014;15:21703-22.

22. Adams BK, Ferstl EM, Davis MC, Herold M, Kurtkaya S, Camalier RF, et al. Synthesis and biological evaluation of novel curcumin analogs as anticancer and anti-angiogenesis agents. Bioorg Med Chem. 2004;12:3871-83.

23. Adams BK, Cai J, Armstrong J, Herold M, Lu YJ, Sun A, et al. EF24, a novel synthetic curcumin analog, induces apoptosis in cancer cells via a redoxdependent mechanism. Anticancer Drugs. 2005;16:263-75.

24. Kearns PR, Hall AG. Glutathione and the response of malignant cells to chemotherapy. Drug Discov Today. 1998;3:113-21.

25. Espinoza-Fonseca $L M$. The benefits of the multi-target approach in drug design and discovery. Bioorg Med Chem. 2006;14:896-7.

26. Frantz S. Playing dirty. Nature. 2005;437:942-3.

27. Block Kl, Gyllenhaal C, Lowe L, Amedei A, Ruhul Amin ARM, Amin A, et al. Designing a broad-spectrum integrative approach for cancer prevention and treatment. Semin Cancer Biol. 2015;35(Suppl):S276-304.

28. Das S, Das U, Varela-Ramírez A, Lema C, Aguilera RJ, Balzarini J, et al. Bis [3,5bis (benzylidene)-4-oxo-1-piperidinyllamides: a novel class of potent Cytotoxins. ChemMedChem. 2011;6:1892-9.

29. Das S, Das U, Sakagami H, Umemura N, Iwamoto S, Matsuta T, et al. Dimeric 3,5bis (benzylidene)-4-piperidones: a novel cluster of tumour-selective cytotoxins possessing multidrug-resistant properties. Eur J Med Chem. 2012;51:193-9.

30. Santiago-Vazquez Y, Das S, Das U, Robles-Escajeda E, Ortega NM, Lema C, et al. Novel 3,5-bis (arylidene)-4-oxo-1-piperidinyl dimers: structure-activity relationships and potent antileukemic and antilymphoma cytotoxicity. Eur J Med Chem. 2014;77:315-22.

31. Das S, Das U, Michel D, Gorecki DKJ, Dimmock JR. Novel 3,5-bis (arylidene)4-piperidone dimers: potent cytotoxins against colon cancer cells. Eur J Med Chem. 2013;64:321-8.

32. Edlich RF, Winters KL, Lin KY. Breast cancer and ovarian cancer genetics. J Long Term Eff Med Implants. 2005;15:533-45.

33. Kavitha CV, Nambiar M, Ananda Kumar CS, Choudhary B, Muniyappa K, Rangappa KS, et al. Novel derivatives of spirohydantoin induce growth inhibition followed by apoptosis in leukemia cells. Biochem Pharmacol. 2009;77:348-63.

34. Allen M, Millett P, Dawes E, Rushton N. Lactate dehydrogenase activity as a rapid and sensitive test for the quantification of cell numbers in vitro. Clin Mater. 1994;16:189-94.

35. Kim R. Recent advances in understanding the cell death pathways activated by anticancer therapy. Cancer. 2005;103:1551-60.

36. Boersma HH, Kietselaer BLJH, Stolk LML, Bennaghmouch A, Hofstra L, Narula $\mathrm{J}$, et al. Past, present, and future of annexin A5: from protein discovery to clinical applications. J Nucl Med. 2005;46:2035-50.

37. Porter AG, Jänicke RU. Emerging roles of caspase-3 in apoptosis. Cell Death Differ. 1999;6:99-104.

38. Mcllwain DR, Berger T, Mak TW. Caspase functions in cell death and disease. Cold Spring Harb Perspect Biol. 2013;5:1-28.

39. Chambers AF, Groom AC, MacDonald IC. Dissemination and growth of cancer cells in metastatic sites. Nat Rev Cancer. 2002;2:563-72.

40. Al-Akhras MAH, Aljarrah K, Al-Khateeb H, Jaradat A, Al-Omari A, Al-Nasser A, et al. Introducing cichorium pumilum as a potential therapeutical agent against drug-induced benign breast tumor in rats. Electromagn Biol Med. 2012;31:299-309.

41. Hamza AA, Heeba GH, Elwy HM, Murali C, El-Awady R, Amin A. Molecular characterization of the grape seeds extract's effect against chemically induced liver cancer: in vivo and in vitro analyses. Sci Rep. 2018;8:1270.

42. Lotempio MM, Veena MS, Steele HL, Ramamurthy B, Ramalingam TS, Cohen AN, et al. Curcumin suppresses growth of head and neck squamous cell carcinoma. Clin Cancer Res. 2005;11:6994-7002.

43. Mukhopadhyay A, Bueso-Ramos C, Chatterjee D, Pantazis P, Aggarwal BB. Curcumin downregulates cell survival mechanisms in human prostate cancer cell lines. Oncogene. 2001;20:7597-609. 
44. Siwak DR, Shishodia S, Aggarwal BB, Kurzrock R. Curcumin-induced antiproliferative and proapoptotic effects in melanoma cells are associated with suppression of $\mathrm{K} B$ kinase and nuclear factor $\mathrm{KB}$ activity and are independent of the B-Raf/mitogen-activated/ extracellular signal-regulated protein kinase pathway and the Akt pathway. Cancer. 2005;104:879-90.

45. Mehta K, Pantazis P, McQueen T, Aggarwal BB. Antiproliferative effect of curcumin (diferuloylmethane) against human breast tumor cell lines. Anticancer Drugs. 1997:8:470-81.

46. Elattar TMA, Virji AS. The inhibitory effect of curcumin, genistein, quercetin and cisplatin on the growth of oral cancer cells in vitro. Anticancer Res. 2000;20:1733-8

47. Lin YG, Kunnumakkara AB, Nair A, Merritt WM, Han LY, Armaiz-Pena GN, et al. Curcumin inhibits tumor growth and angiogenesis in ovarian carcinoma by targeting the nuclear factor-kB pathway. Clin Cancer Res. 2007;13:3423-30.

48. Ye C, Wang W, Xia G, Yu C, Yi Y, Hua C, et al. A novel curcumin derivative CL-6 exerts antitumor effect in human gastric cancer cells by inducing apoptosis through hippo-YAP signaling pathway. OncoTargets Therapy. 2019:12:2259-69.

49. Vyas A, Dandawate P, Padhye S, Ahmad A, Fazlul S. Perspectives on new synthetic curcumin analogs and their potential anticancer properties. Curr Pharm Des. 2013;19:2047-69.

50. Shi M, Cai Q, Yao L, Mao Y, Ming Y, Ouyang G. Antiproliferation and apoptosis induced by curcumin in human ovarian cancer cells. Cell Biol Int 2006;30:221-6

51. Zeuthen J. Human teratocarcinoma cell lines. A review. Int J Androl. 1981;4:61-77

52. Zeuthen J, Norgaard JO, Avner P, Fellous M, Wartiovaara J, Vaheri A, et al. Characterization of a human ovarian teratocarcinoma-derived cell line. Int J Cancer. 1980:25:19-32.

53. Lawson DA, Bhakta NR, Kessenbrock K, Prummel KD, Yu Y, Takai K, et al. Single-cell analysis reveals a stem-cell program in human metastatic breast cancer cells. Nature. 2015;526:131-5.

54. Morata-Tarifa C, Jiménez G, García MA, Entrena JM, Griñán-Lisón C, Aguilera $M$, et al. Low adherent cancer cell subpopulations are enriched in tumorigenic and metastatic epithelial-to-mesenchymal transition-induced cancer stem-like cells. Sci Rep. 2016;6:18772.

55. Zhang QH, Dou HT, Xu P, Zhuang SC, Liu PS. Tumor recurrence and drug resistance properties of side population cells in high grade ovary cancer. Drug Res. 2015;65:153-7.

56. Li SS, Ma J, Wong AST. Chemoresistance in ovarian cancer: exploiting cancer stem cell metabolism. J Gynecol Oncol. 2018;29:e32.

57. Dean M, Fojo T, Bates S. Tumour stem cells and drug resistance. Nat Rev Cancer. 2005;5:275-84.

58. Singh A, Settleman J. EMT, cancer stem cells and drug resistance: an emerging axis of evil in the war on cancer. Oncogene. 2010;29:4741-51.

59. Yamamoto M, Suzuki S, Togashi K, Sanomachi T, Seino S, Kitanaka C, et al. AS602801, an anticancer stem cell candidate drug, reduces survivin expression and sensitizes A2780 ovarian cancer stem cells to carboplatin and paclitaxel. Anticancer Res. 2018;38:6699-706.

60. Raghavan S, Mehta P, Ward MR, Bregenzer ME, Fleck EMA, Tan L, et al. Personalized medicine-based approach to model patterns of chemoresistance and tumor recurrence using ovarian cancer stem cell spheroids. Clin Cancer Res. 2017;23:6934-45.

61. Jensen PB, Christensen IJ, Sehested M, Hansen HH, Vindeløv L. Differential cytotoxicity of 19 anticancer agents in wild type and etoposide resistant small cell lung cancer cell lines. Br J Cancer. 1993;67:311-20.

62. ATCC. Triple negative breast cancer panels- MDA-MB-231 WwwAtccOrg; 2004.

63. Pal SK, Childs BH, Pegram M. Triple negative breast cancer: unmet medical needs. Breast Cancer Res Treat. 2011;125:627-36.

64. Neve RM, Chin K, Fridlyand J, Yeh J, Baehner FL, Fevr T, et al. A collection of breast cancer cell lines for the study of functionally distinct cancer subtypes. Cancer Cell. 2006;10:515-27.

65. Cailleau R, Olivé M, Cruciger QVJ. Long-term human breast carcinoma cell lines of metastatic origin: preliminary characterization. In Vitro. 1978;14:911-5.

66. Holliday DL, Speirs V. Choosing the right cell line for breast cancer research. Breast Cancer Res. 2011;13:215.

67. Ahmed Wahba $\mathrm{H}$, Ahmed E-HH. Current approaches in treatment of triplenegative breast cancer. Cancer Biol Med. 2015;12:106-16.

68. Mehlen P, Puisieux A. Metastasis: a question of life or death. Nat Rev Cancer. 2006;6:449-58.
69. Kuttan G, Hari Kumar KB, Guruvayoorappan C, Kuttan R. Antitumor, antiinvasion, and antimetastatic effects of curcumin. Adv Exp Med Biol. 2007; 595:173-84.

70. Thiery JP, Acloque H, Huang RYJ, Nieto MA. Epithelial-mesenchymal transitions in development and disease. Cell. 2009;139:871-90.

71. Polyak K, Weinberg RA. Transitions between epithelial and mesenchymal states: acquisition of malignant and stem cell traits. Nat Rev Cancer. 2009;9: 265-73.

72. Herreros-Villanueva M, Zhang JS, Koenig A, Abel EV, Smyrk TC, Bamlet WR, et al. SOX2 promotes dedifferentiation and imparts stem cell-like features to pancreatic cancer cells. Oncogenesis. 2013;2:e61.

73. Liu H, Kato Y, Erzinger SA, Kiriakova GM, Qian Y, Palmieri D, et al. The role of MMP-1 in breast cancer growth and metastasis to the brain in a xenograft model. BMC Cancer. 2012;12:583.

74. Negroni A, Cucchiara S, Stronati L. Apoptosis, necrosis, and necroptosis in the gut and intestinal homeostasis. Mediators Inflamm. 2015;2015:250762.

75. Friesen C, Fulda S, Debatin KM. Cytotoxic drugs and the CD95 pathway. Leukemia. 1999;13:1854-8.

76. Tameire F, Verginadis II, Koumenis C. Cell intrinsic and extrinsic activators of the unfolded protein response in cancer: mechanisms and targets for therapy. Semin Cancer Biol. 2015;33:3-15.

77. Fulda S, Debatin KM. Extrinsic versus intrinsic apoptosis pathways in anticancer chemotherapy. Oncogene. 2006;25:4798-811.

78. COHEN GM. Caspases: the executioners of apoptosis. Biochem J. 1997:326:1-16.

79. Elmore S. Apoptosis: a review of programmed cell death. Toxicol Pathol. 2007;35:495-516.

\section{Publisher's Note}

Springer Nature remains neutral with regard to jurisdictional claims in published maps and institutional affiliations.

Ready to submit your research? Choose BMC and benefit from:

- fast, convenient online submission

- thorough peer review by experienced researchers in your field

- rapid publication on acceptance

- support for research data, including large and complex data types

- gold Open Access which fosters wider collaboration and increased citations

- maximum visibility for your research: over $100 \mathrm{M}$ website views per year

At $\mathrm{BMC}$, research is always in progress.

Learn more biomedcentral.com/submissions 